\title{
Article/Artigo
}

\section{Digoxin serum levels in patients with Chagas' cardiomyopathy and heart failure}

\author{
Níveis séricos de digoxina em pacientes com insuficiência cardíaca secundária à cardiomiopatia \\ da doença de Chagas
}

\section{Samira Jorge Ferrari ${ }^{1}$, Reinaldo Bulgarelli Bestetti ${ }^{1}$, Augusto Cardinalli-Neto ${ }^{1}$ and Talita Bottan Bortoluzzi ${ }^{1}$}

\begin{abstract}
Introduction: The purpose of this study was to determine digoxin serum concentrations in patients with Chagas' cardiomyopathy with chronic heart failure, because little is known concerning this laboratory test in patients with this condition. Methods: This study focuses on 29 (29\%) out of 101 patients with chronic heart failure secondary to Chagas' cardiomyopathy receiving digoxin therapy. Digoxin was measured by the immune-enzymatic method. Results: New York Heart Association Functional Class III/IV was noted in 13 (45\%) patients. The mean potassium serum level was $4.3 \pm 0.5 \mathrm{mEq} / \mathrm{L}$, mean creatinine serum levels $1.4 \pm 0.3 \mathrm{dg} / 100 \mathrm{ml}$, and left ventricular ejection fraction $34.7 \pm 13.8 \%$. The median digoxin serum level was 1.27 $(0.55 ; 1.79) \mathrm{ng} / \mathrm{ml}$. Sixteen $(55 \%)$ patients had digoxin serum levels higher than $1.0 \mathrm{ng} / \mathrm{ml}$. Abnormal digoxin serum levels were verified in 13 (45\%) patients. Digoxin serum levels correlated moderately with creatinine serum levels $(r=0.39 ; \mathrm{p} \leq 0.03)$ and negatively with sodium serum levels $(r=-0.38 ; p=0.03)$. Conclusions: Digoxin serum concentration should be measured in patients with Chagas' cardiomyopathy with chronic heart failure receiving digoxin therapy due to the potential for digoxin toxicity.
\end{abstract}

Key-words: Chagas' disease. Trypanosomiasis American. Chronic Heart failure. Digoxin. Cardiomyopathy.

\section{RESUMO}

Introdução: $\mathrm{O}$ propósito deste trabalho foi o de determinar a concentração sérica de digoxina em pacientes com insuficiência cardíaca crônica secundária à cardiomiopatia da doença de Chagas porque pouco se conhece sobre os níveis séricos desse fármaco em pacientes com tal condição clínica. Métodos: Foram recrutados 29 (29\%) de 101 pacientes com insuficiência cardíaca crônica secundária à cardiomiopatia da doença de Chagas, os quais estavam sendo tratados com digoxina. Essa droga foi medida no soro desses pacientes pelo método imunoenzimático. Resultados: Treze (45\%) pacientes estavam no grau III/ IV da Sociedade Nova-Iorquina de Cardiologia. Os níveis séricos de potássio médio foram $4,3 \pm 0,5 \mathrm{mEq} / \mathrm{L}$, a creatinina sérica média $1,4 \pm 0,3 \mathrm{dg} / 100 \mathrm{ml}$, e a fração de ejeção do ventrículo esquerdo $34.7 \pm 13.8 \%$. Os níveis séricos médios de digoxina foram $1,27(0,55 ; 1,79) \mathrm{ng} / \mathrm{ml}$. Dezesseis $(55 \%)$ pacientes apresentaram níveis séricos de digoxina $>1,0 \mathrm{ng} / \mathrm{ml}$. Níveis séricos anormais de digoxina foram observados em 13 (45\%) pacientes. Os níveis séricos de digoxina correlacionaram moderadamente com os de creatinina $(r=0,39 ; \mathrm{p} \leq 0,03)$ e negativamente com os de sodium $(r=-0,38 ; p=0,03)$. Conclusões: Os níveis séricos de digoxina devem ser medidos em pacientes com insuficiência cardíaca crônica secundária à cardiomiopatia da doença de Chagas por causa do potencial para ocorrer toxicidade pela digoxina.

Palavras-chaves: Doença de Chagas. Trypanosomiasis americana. Insuficiência cardíaca crônica. Digoxina. Cardiomiopatia.

1. Department of Cardiology and Cardiovascular Surgery, Base Hospital, Faculty of Medicine of São José do Rio Preto, São José do Rio Preto, SP, Brazil.

Address to: Dr. Reinaldo Bulgarelli Bestetti. Setor de Eletrocardiografia/Hospital de Base. Av. Faria Lima 5544, 15090-000 São José do Rio Preto, SP, Brazil.

Fax: $55173201-5065$

e-mail: rbestetti@netsite.com.br

Received in $11 / 03 / 2010$

Accepted in 13/07/2010

\section{INTRODUCTION}

Chagas' disease, a tropical disease caused by the protozoan Trypanosoma cruzi, is a major public health problem in Latin America, since it affects 18 million people and another 100 million are at risk of acquiring the disease ${ }^{1}$. In view of international immigration, Chagas' disease now affects almost 700,000 people outside Latin America ${ }^{2}$.

Chronic heart failure is a protean clinical manifestation of chronic Chagas' disease. In fact, it is the leading cause of chronic heart failure in areas where the disease is endemic ${ }^{3}$, its prognosis is worse than that observed in non-Chagas' disease heart failure ${ }^{3,4}$ and affects about $4 \%$ to $8 \%$ of outpatients living in rural areas and up to $76 \%$ of patients followed at a tertiary referral center 5 . Digoxin is an integral component of the pharmacological armamentarium for the treatment of chronic systolic heart failure secondary to Chagas' cardiomyopathy, particularly for patients in New York Heart Association Class III or IV ${ }^{5}$.

In patients with non-Chagas' disease heart failure, chronic digoxin therapy has no impact on all-cause mortality, but decreases the combination of death or hospitalization ${ }^{6}$. However, Rathore et $\mathrm{al}^{7}$ have shown that all-cause mortality is higher in patients with serum digoxin concentration $>1.2 \mathrm{ng} /$ $\mathrm{ml}$ in comparison to patients with serum digoxin concentrations $\leq 1.2 \mathrm{ng} / \mathrm{ml}$. More recently, studies have suggested that survival may be improved in patients in whom digoxin serum concentrations are lower $(0.5$ to $1.0 \mathrm{ng} / \mathrm{ml})$ than those previously recommended ( 0.8 to $2.0 \mathrm{ng} / \mathrm{ml})^{8-10}$.

In patients with chronic heart failure secondary to Chagas' cardiomyopathy, digoxin serum levels have not routinely been measured thus far, mainly due to economic reasons or lack of proper apparatus to measure it in poor areas. Since the presence of atrioventricular, fascicular and branch block altogether are more common in Chagas' than in nonChagas' disease heart failure patients, the potential for advanced heart blocks mediated by digoxin toxicity is probably greater in the former group. 
In addition, the peculiarities of histological aspects observed in this disease, confluent foci of fibrosis along with mononuclear cell infiltrate throughout the myocardium, similar to that which occurs in catecholamine cardiomyopathy ${ }^{11-12}$, may predispose Chagas' disease patients receiving digoxin therapy to malignant ventricular arrhythmias and ultimately death. In fact, it has been shown that digoxin use may negatively affect survival in Chagas' disease heart failure patients ${ }^{13}$.

Therefore, this study, aimed to determine the prevalence of abnormal and/or high ( $>1 \mathrm{ng} / \mathrm{ml})$ digoxin serum concentrations in patients with Chagas' cardiomyopathy with chronic heart failure.

\section{METHODS}

\section{Patients}

From January 2000 to October 2007, 231 patients with chronic heart failure secondary to Chagas' cardiomyopathy were admitted to the outpatient Cardiomyopathy Service of Hospital de Base. The diagnosis of Chagas' disease was confirmed based on positive serology. Approximately 120 (50\%) patients died during the above period. Of the remaining 101 patients, 29 (29\%) were receiving digoxin therapy.

Previous patient work-up consisted of anamnesis, physical examination, standard laboratory tests, 12-lead electrocardiogram, chest $\mathrm{X}$-Ray and 2-dimensional trans-thoracic Doppler-echocardiography.

Digoxin was administered as previously described, in the morning, by oral route, according to age $(0.125 \mathrm{mg} /$ day per patients aged $>65$ years, and $0.25 \mathrm{mg} /$ day per patient aged $<65$ years $)^{8}$.

\section{Digoxin study}

All digoxin serum levels measurements were performed in the morning following 12 -hour fasting by the patient. The last digoxin ingestion occurred 24 hours before measurement. A blood sample was collected from the antecubital vein from each patient. The blood was centrifuged, stored at $-20^{\circ}$ and measured by the immuneenzymatic method.

\section{Statistical analysis}

Continuous variables with normal distribution are expressed as mean \pm standard deviation, whereas those with nonnormal distribution are presented as median ( $25 \%$ percentile, $75 \%$ percentile). Categorical variables are shown as proportions (\%). One-way ANOVA was used to compare continuous variables when appropriate. Categorical variables were compared by the $\mathrm{X}^{2}$ test. The Spearman test was used to establish correlations between continuous variables and digoxin serum levels. Correlation between two continuous variables was settled at an $r$ level $\geq 0.30$ and $p$ value $<0.05$. Differences for a $p$ level $<0.05$ were considered statistically significant.

\section{Ethical}

The study was approved by the local ethics in research committee (Protocol 4464/2008). The small risk of complications associated with venous puncture was explained to each patient. After free, informed consent was obtained, digoxin measurement was performed.

\section{RESULTS}

Patient mean age was $60 \pm 12$ years-old, 18 (62\%) were males. At the time of digoxin measurement, New York Heart Association Functional Class III/IV was registered for 13 (45\%) patients. The mean sodium serum level was $139.4 \pm 3.9 \mathrm{mEq} / \mathrm{L}$, the mean potassium serum level was $4.3 \pm 0.5 \mathrm{mEq} / \mathrm{L}$ and the mean creatinine serum level was $1.4 \pm 0.3 \mathrm{dg} / 100 \mathrm{ml}$. Angiotensin converting enzyme inhibitor or Losartan was administered to $23(79 \%)$ patients, furosemide to 26 (90\%), spironolactone to 18 (62\%), amiodarone to $11(38 \%)$, and B-blockers to $19(66 \%)$ patients. The 12-lead ECG was available for 28 patients. Atrial fibrillation was verified in 7 (25\%) patients, right bundle branch block in 4 (14\%), left anterior fascicular block in $10(36 \%)$ and ventricular premature contractions in $11(38 \%)$. patients. Regarding chest radiograph, available for 27 patients, pulmonary venous congestion was verified in 12 (44\%) patients. Concerning echocardiography, left atrium enlargement was detected in $22(76 \%)$ patients and right ventricular enlargement in $6(21 \%)$. The mean left ventricular systolic dimension was $54 \pm 10.3 \mathrm{~mm}$, the mean left ventricular diastolic dimension was $62.3 \pm 13.2 \mathrm{~mm}$ and the mean left ventricular ejection fraction was $34.7 \pm 13.8 \%$.

The median digoxin serum level was $1.27(0.55 ; 1.79) \mathrm{ng} /$ $\mathrm{ml}$. Sixteen (55\%) patients had digoxin serum levels $\geq 1.0 \mathrm{ng} / \mathrm{ml}$, 9 (31\%) digoxin serum levels $\geq 1.5 \mathrm{ng} / \mathrm{ml}$ (the upper limit) and 4 (14\%) digoxin serum levels $\geq 2.5 \mathrm{ng} / \mathrm{ml}$ (toxic effect in the DIG trial), as illustrated in Figure 1.

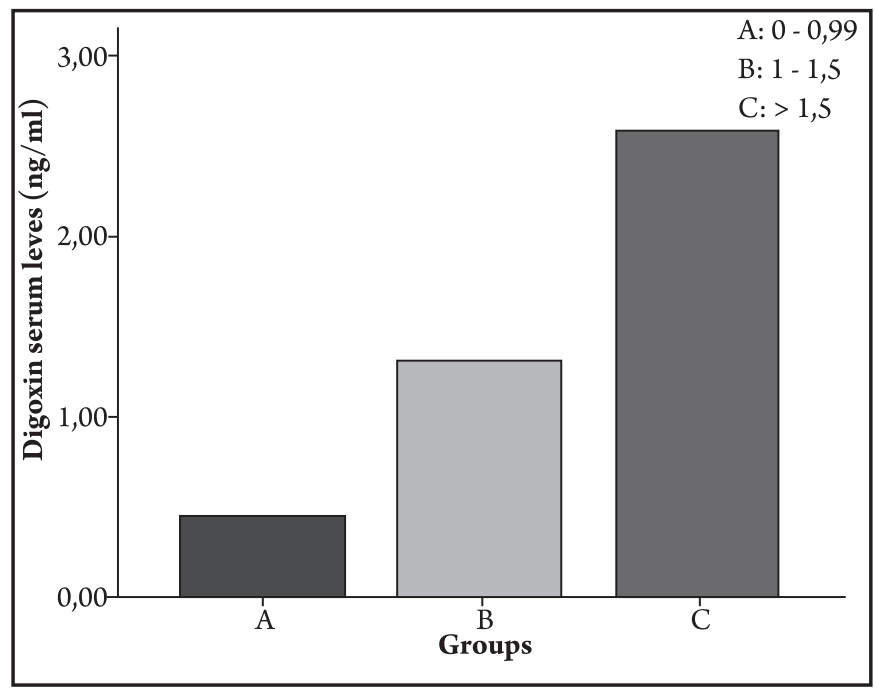

FIGURE 1 - Digoxin serum levels in patients with Chagas' cardiomyopathy with chronic heart failure.

Digoxin serum levels correlated moderately with creatinine serum levels $(\mathrm{r}=0.39 ; \mathrm{p}<0.03)$ and negatively with sodium serum levels $(\mathrm{r}=-0.38 ; \mathrm{p}=0.03)$. No correlation occurred between digoxin serum levels and potassium $(r=-10 ; p>0.05)$ and age $(r=0.26$; $\mathrm{p}>0.05)$. No correlation was verified between digoxin serum levels and left ventricular systolic dimension $(r=-0.17 ; \mathrm{p}>0.05)$, left ventricular diastolic dimension $(r=0.07 ; \mathrm{p}>0.05)$ or left ventricular ejection fraction $(r=-0.22 ; \mathrm{p}>0.05)$.

Pulmonary venous congestion was verified in 5 (45\%) out of 12 patients with digoxin serum concentration $<1 \mathrm{ng} / \mathrm{ml}$ and in 7 (44\%) out of 16 patients with digoxin serum levels $\geq 1 \mathrm{ng} / \mathrm{ml}$ $(\mathrm{p}>0.05)$. Table 1 presents a comparison of clinical parameters between patients with digoxin serum levels $\geq 1 \mathrm{ng} / \mathrm{ml}$ and patients with digoxin serum levels $<1 \mathrm{ng} / \mathrm{ml}$. The proportion of patients on spironolactone was higher in patients with digoxin serum levels $\geq 1 \mathrm{ng} / \mathrm{ml}$. 
TABLE 1 - Comparison of clinical characteristics of patients with digoxin serum levels $<1 \mathrm{ng} / \mathrm{ml}(\mathrm{n}=13)$ and with digoxin serum levels $\geq 1 \mathrm{ng} / \mathrm{ml}(\mathrm{n}=16)$.

\begin{tabular}{lcc}
\hline & DSL $<\mathbf{1} \mathbf{~ n g} / \mathbf{m l}$ & DSL $\geq \mathbf{1} \mathbf{~ n g} / \mathbf{m l}$ \\
\hline Age (years) & $59 \pm 13$ & $61 \pm 12$ \\
Male & $9(69 \%)$ & $9(56 \%)$ \\
NYHA Class III/IV & $6(46 \%)$ & $7(44 \%)$ \\
ACEI & $10(77 \%)$ & $13(81 \%)$ \\
Furosemide & $11(85 \%)$ & $15(94 \%)$ \\
Spironolactone & $5(38 \%)$ & $13(81 \%)^{*}$ \\
B-blockers & $9(69 \%)$ & $10(62 \%)$ \\
Atrial fibrillation** & $4(36 \%)$ & $3(19 \%)$ \\
Right bundle branch block ${ }^{* *}$ & $1(8 \%)$ & $3(19 \%)$ \\
Left anterior hemiblock** & $6(46 \%)$ & $4(25 \%)$ \\
Ventricular premature contractions & $5(38 \%)$ & $6(37 \%)$ \\
LVDD (mm) & $62.4 \pm 18.2$ & $62.2 \pm 7.6$ \\
LVSD (mm) & $55.7 \pm 11.4$ & $52.7 \pm 9.4$ \\
LVEF (\%) & $37.9 \pm 13.2$ & $32.3 \pm 14$ \\
LAE & $11(85 \%)$ & $11(69 \%)$ \\
RVD & $2(15 \%)$ & $4(25 \%)$ \\
\hline
\end{tabular}

${ }^{*} \mathrm{p}=0.03,{ }^{* *} 12$ patients studied in patients with $\mathrm{SDL}<1 \mathrm{ng} / \mathrm{ml}$.

DSL: digoxin serum levels, NYHA: New York Heart Association, ACEI: angiotensin converting enzyme inhibitors, LVDD: left ventricular diastolic dimension, LVSD: left ventricular systolic dimension, LVEF: left ventricular ejection fraction, LAE: left atrial enlargement, RVD: right ventricular dilatation.

\section{DISCUSSION}

This cross-sectional study shows that roughly half of Chagas' disease patients with chronic heart failure in need of digoxin therapy present higher serum digoxin concentration than that currently recommended. This fact highlights the necessity of measuring digoxin in the serum of such patients to provide the best treatment available for patients with this condition.

Mean age was similar in patients with digoxin serum levels $\geq 1 \mathrm{ng} / \mathrm{ml}$ and in those with digoxin serum concentrations $<1 \mathrm{ng} /$ $\mathrm{ml}$. In contrast, mean age was higher in patients with serum digoxin concentrations $\geq 1 \mathrm{ng} / \mathrm{ml}$ in the DIG trial ${ }^{8}$. In this study, however, mean age was slightly lower than that reported for the DIG trial ${ }^{8}$. It is conceivable, therefore, that this difference accounts for the disparity observed between these studies.

The proportion of patients with pulmonary congestion, as shown by the chest radiograph, was similar in patients with serum digoxin concentration $\geq 1 \mathrm{ng} / \mathrm{ml}$ and in those with serum digoxin concentration $<1 \mathrm{ng} / \mathrm{ml}$. This is in contrast with that has been verified in non-Chagas' disease heart failure ${ }^{8}$. Perhaps this discrepancy can be explained by B-Blocker therapy, which is known to increase left ventricular ejection fraction and to decrease pulmonary congestion, but was not used at the time the DIG trial was conducted, but was used in the majority of patients enrolled in this study.

There was no difference in potassium serum levels in patients with digoxin serum concentration $\geq 1 \mathrm{ng} / \mathrm{ml}$ in comparison to patients with digoxin serum concentration $<1 \mathrm{ng} / \mathrm{ml}$ in our investigation, despite the fact that $90 \%$ of patients were receiving furosemide and $66 \%$ spironolactone at the time of digoxin measurement. Moreover, the mean potassium serum level was below the normal range. This fact is in agreement with that reported for the DIG trial ${ }^{8}$.
A key point in this investigation was the fact that about $66 \%$ of patients received B-blockers at targeted dose along with digoxin. In non-Chagas' disease patients, B-blocker therapy benefits both patients administered and those not administered digoxin as treatment for chronic heart failure ${ }^{14}$. In the context of Chagas' disease, B-blocker therapy has been shown to provide beneficial effects experimentally ${ }^{15}$, as well as in patients with chronic heart failure $^{16}$. Nonetheless, B-blocker therapy is not devoid of potential complications in Chagas' disease patients.

In fact, carvedilol increases digoxin serum concentration in nonChagas' disease patients with chronic heart failure, mainly in men ${ }^{17}$. Given the presence of a high frequency of patients with bundle branch and fascicular blocks in Chagas' disease with chronic heart failure, as detected in our study, such an increase in digoxin serum concentration could lead to the appearance of life-threatening arrhythmias ${ }^{18}$ due to macroreentry and atrioventricular blocks ${ }^{19}$, cardinal manifestations of digoxin toxicity. Nevertheless, the proportion of patients on B-blockers with digoxin serum concentrations $\geq 1 \mathrm{ng} / \mathrm{ml}$ was similar to that verified in patients on B-blockers with digoxin serum concentrations $<1 \mathrm{ng} / \mathrm{ml}$. Another property of B-blockers, therefore, might have counteracted this potential deleterious effect.

Carvedilol has been shown to decrease proinflammatory cytokine levels in non-Chagas' disease patients with chronic heart failure on digoxin therapy ${ }^{20}$. Proinflammatory cytokines, particularly TNF, are increased in patients with chronic heart failure secondary to Chagas' cardiomyopathy ${ }^{21}$. The interplay of spasm in the small intramyocardial coronary vessels, autoimmunity and parasympathetic impairment is believed to play a role in the pathogenesis of Chagas' cardiomyopathy ${ }^{22}$. In Chagas' disease patients, therefore, TNF could lead to microvascular thrombosis-induced myocardial ischemia, as well as orchestrating chronic myocardial inflammation and ultimately reparative myocardial fibrosis ${ }^{11}$. Thus, B-blocker therapy added to patients with chronic heart failure with Chagas' cardiomyopathy on digoxin therapy does not appear to be detrimental, as observed prior to the current era of heart failure therapy ${ }^{23}$.

Digoxin has not been routinely measured in patients with Chagas' cardiomyopathy with chronic heart failure due to economic reasons, inasmuch as this laboratory test is not paid for by the National Health System. It has not also been determined in distant rural areas, where the disease is endemic, due to the unavailability of proper apparatus to perform the immune-enzymatic method. This study shows the necessity to measure digoxin serum levels in Chagas' disease heart failure patients because of the potential for digoxin toxicity, as observed in non-Chagas' disease heart failure patients.

The main limitation of the present investigation is the small sample size. Thus, a multicentric study analyzing more patients with this condition would be necessary to confirm the results obtained in this work. Nonetheless, it must be emphasized that this investigation was conducted in a tertiary referral center where Chagas' disease patients are routinely followed, thus reflecting the reality of the proper treatment of such patients in daily practice.

In conclusion, the prevalence of abnormal digoxin serum concentration is high in patients with chronic heart failure secondary to Chagas' cardiomyopathy. Further studies are necessary to confirm the results of this investigation.

\section{CONFLICT OF INTEREST}

The authors declare that there is no conflict of interest. 


\section{FINANCIAL SUPPORT}

From the Fundação de Amparo à Pesquisa do Estado de São Paulo (FAPESP). Samira Jorge Ferrari and Talita Bottan Bortoluzzi are recipients of Bolsa de Iniciação Científica from the Conselho Nacional de Pesquisa (CNPq).

\section{REFERENCES}

1. Anonymous. A human rights-based approach to neglected tropical diseases. Available from: http:// apps.who.int/tdr/svc/publication/tdr.research publications/human rights/. (Accessed on August 20, 2009).

2. Schmunis GA. Epidemiology of Chagas disease in non-endemic countries: the role of international migration. Mem Inst Oswaldo Cruz 2007; 102(suppl1) $75-85$.

3. Bestetti RB, Muccillo G. Clinical course of Chagas' heart disease: a comparison with dilated cardiomyopathy. Int J Cardiol 1997; 60:187-193.

4. Freitas HFG, Chizzola PR, Paes AT, Lima ACP, Mansur AJ. Risk stratification in a Brazilian hospital-based cohort of 1220 outpatients with heart failure: role of Chagas' heart disease. Int J Cardiol 2005; 102:239-247.

5. Bestetti RB, Theodoropoulos TAD, Cardinalli-Neto A, Cury PM. Treatment of chronic systolic heart failure secondary to Chagas heart disease in the current era of heart failure therapy. Am Heart J 2008; 156:422-430.

6. DIG trial investigators. The effect of digoxin on mortality and morbidity in patients with heart failure. N Engl J Med 1997; 336:525-533.

7. Rathore S, Curtis JP, Wang Bristow MR, Krumholz HM. Association of serum digoxin concentration and outcomes in patients with heart failure. J Am Med Assoc 2003; 289:871-878.

8. Ahmed A, Rich MW, Love TE, Lloyd-Jones DM, Aban IB, Colucci WS, et al. Digoxin and reduction in mortality and hospitalization in heart failure: a comprehensive post hoc analysis of the DIG trial. Eur Heart J 2006; 27: $178-186$

9. Ahmed A, Pitt B, Rahimtoola SH, Ahmed A, Waagstein F, White M, et al. Effects of digoxin at low serum concentrations on mortality and hospitalization in heart failure: a propensity-matched study of the DIG trial. Int J Cardiol 2008; 123:138-146.

10. Ahmed A, Waagenstein F, Pitt B, White M, Zannad F, Young JB, et al. Effectiveness of digoxin in reducing one-year mortality in chronic heart failure in the Digitalis investigation group trial. Am J Cardiol 2009; 103:82-87.

11. Rossi MA, Ramos SG, Bestetti RB. Chagas' heart disease: clinical-pathological correlation. Front Biosci 2003; 8:e94-109.

12. Bestetti RB, Ramos CP, Figueredo-Silva J, Sales-Neto VN, Oliveira JSM. Ability of the electrocardiogram to detect myocardial lesions in isoproterenol-induced rat cardiomyopathy. Cardiovasc Res 1987; 21:916-921.

13. Theodoropoulos TAD, Bestetti RB, Otaviano AP, Cordeiro JA, Rodrigues VC, Silva AC. Predictors of all-cause mortality in chronic Chagas' heart disease in the current era of heart failure therapy. Int J Cardiol 2008; 128:22-29.

14. Eichorn EJ, Lukas MA, Wu B, Shusterman N. Effect of concomitant digoxin and carvedilol therapy on mortality and morbidity in patients with chronic heart failure. Am J Cardiol 2000; 86:1032-1035.

15. Bestetti RB, Sales-Neto VN, Pinto LZ, Soares EG, Muccillo G, Oliveira JS. Effects of long term metoprolol administration on the electrocardiogram of rats infected with T cruzi. Cardiovasc Res 1990; 24:521-527.

16. Issa VS, Amaral AF, Cruz FD, Ferreira SM, Guimarães GV, Chizzola PR, et al. Beta-blocker therapy and mortality of patients with Chagas cardiomyopathy: a subanalysis of the REMADHE prospective trial. Circ Heart Fail 2010; 3:82-88.

17. Baris N, Kalkan S, Guneri S, Bozdemir V, Guven H. Influence of carvedilol on serum digoxin levels in heart failure: is there any gender difference? Eur J Clin Pharmacology 2006; 62:535-538.

18. Bestetti RB, Santos CRF, Machado-Jr OB, Ariolli MT, Carmo JL, Costa NK, et al. Clinical profile of patients with Chagas' disease before and during ventricular tachycardia. Int J Cardiol 1990; 29:39-46.
19. Bestetti RB, Cardinalli-Neto A. Sudden cardiac death in Chagas ' heart disease in the contemporary era. Int J Cardiol 2008; 131:9-17.

20. Tatli E, Kurum T, Aktoz M, Buyuklu M. Effects of carvedilol on right ventricular ejection fraction and cytokines levels in patients with systolic heart failure. Int J Cardiol 2008; 125:273-276.

21. Ferreira RC, Ianni BM, Abel LC, Buck P, Mady C, Kalil J, et al. Increased plasma levels of tumor necrosis factor alpha in asymptomatic "indeterminate" and Chagas" disease cardiomyopathy patients. Mem Inst Oswaldo Cruz 2003; 98:407-411.

22. Bestetti RB. Role of parasites in the pathogenesis of Chagas' cardiomyopathy. Lancet 1996; 347:913-914

23. Barretto ACP, Pileggi FJC. Digital in Chagas' cardiopathy. Arq Bras Cardiol $1982 ; 38: 283-289$. 